\title{
Butterfly, bee and forb community composition and cross-taxon incongruence in tallgrass prairie fragments
}

\section{Authors: Jessica D. Davis, Stephen D. Hendrix, Diane M. Debinski and Chiara J. Hemsley}

The final publication is available at Springer via https://dx.doi.org/10.1007/s10841-006-9063-4.

Jessica Davis, Stephen D. Hendrix, Diane Debinski and Chiara Hemsley. "Butterfly, bee and forb community composition and cross-taxon incongruence in tallgrass prairie fragments" Journal of Insect Conservation Vol. 12 Iss. 1 (2008) DOI: 10.1007/s10841-006-9063-4 


\title{
Butterfly, bee and forb community composition and cross-taxon incongruence in tallgrass prairie fragments
}

\author{
Jessica D. Davis · Stephen D. Hendrix • \\ Diane M. Debinski · Chiara J. Hemsley
}

\begin{abstract}
Pollinators provide an important class of ecological services for crop plants and native species in many ecosystems, including the tallgrass prairie, and their conservation is essential to sustaining prairie remnants. In Iowa these remnants are typically either block-shaped or long, linear strips along transportation routes. In this study we examined differences in the butterfly, bee, and forb community composition in linear and block prairie remnants, determined correlations between species diversity among butterflies, bees and forbs in the 20 prairie remnants sampled, and examined correlations of community similarity among butterflies, bees and forbs. Correspondence analysis showed that distinct communities exist for butterflies and forbs in block versus linear sites and discriminant analysis showed that the bee and forb communities in block and linear sites can be distinguished on the basis of a few species. Diversity of one group was a poor predictor of diversity in another, except for a significant inverse relationship between bees and butterflies. These two pollinator taxa may be responding very differently to microhabitat components within fragmented ecosystems. Our studies show that there need
\end{abstract}

to be differences in conservation strategies for bees and butterflies to maintain both pollinator communities.

Keywords Bees - Butterflies - Correspondence analysis $\cdot$ Cross-taxon congruence $\cdot$ Prairies

\section{Introduction}

Concern over the loss of pollinator diversity and the related ecological and economic consequences has been growing in recent years (Buchmann and Nabhan 1996; Allen-Wardell et al. 1998; Cane and Tepedino 2001; Biesmeijer et al. 2006) as conservationists and others have begun to focus on the previously undervalued ecological services these organisms provide (Constanza et al. 1997, Steffan-Dewenter et al. 2005). The major cause contributing to a loss of pollinator diversity throughout the world is thought to be habitat fragmentation (Rathcke and Jules 1993, SteffanDewenter and Tscharntke 1999) resulting from the conversion of natural habitat to agriculture production. This conversion results in a loss of floral resources that provide the food (nectar and pollen) for all pollinators and the loss of other important resources, such as host plants for butterflies and nest sites for bees. However, conservation of pollinator taxa is impeded because we have few comparative studies of the composition of pollinator communities in different habitat fragments that vary in important characteristics such as shape or size (but see Aizen and Feinsinger 1994, Potts et al. 2003, Cane et al. 2006). Furthermore, it is unclear whether or not high diversity in one pollinator group is indicative of high diversity in other groups or if 
similarity in composition between sites in one group indicates similarity in composition of other groups.

The fragmented landscape of the tallgrass prairie of central North America (with over 99\% destroyed in most states) (Samson and Knopf 1994) provides an ideal system to investigate cross-taxon congruence among pollinator communities in a landscape dominated by agriculture. Remaining tallgrass prairie exists primarily in two forms with distinctive shapes and sizes. There are about 100 relatively large, protected preserves (10-100 ha) that exist as blocks of habitat that are often literally square in shape (Herzberg and Pearson 2001). Additionally there are numerous small ( $<5$ ha), unprotected remnants along transportation routes that occur as relatively long linear strips of remnant prairie. These two shapes predominate among present remnants and will dominate future restorations in agriculturally dominated landscapes because of the interest in roadside restoration and large-scale prairie restorations.

This study focuses on bee and butterfly communities and the forbs they use for pollen and nectar sources in block and linear prairie remnants. Potential complementarity between these pollinator groups is of conservation interest because while butterflies are relatively easy to identify and often are good indicator species of habitat quality (Croxton et al. 2005; Thomas 2005), bees are difficult to identify and their diversity in fragmented landscapes is relatively uninvestigated (but see Steffan-Dewenter and Tscharntke 1999; SteffanDewenter et al. 2002; Cane et al. 2006) making a reliable surrogate indicator for bees valuable. Ecologically, some complimentarity between butterflies, bees and forbs is predicted on the basis that both pollinator groups depend on floral resources as adults. However, these pollinator groups also depend on other resources such as host plants for butterflies and nest sites for bees that may obscure any potential complementarity.

This study addresses three questions. First, does the butterfly, bee, and forb community composition in linear and block native prairie habitats differ? Specifically, we ask if these two site types represent different portions or similar samples of their respective regional communities and if the site types can be recognized on the basis of the abundance of a sample of species. Second, are species diversity among butterflies, bees and forbs in prairie remnants correlated with each other? For example, if a site is high in species diversity of forbs does it also have high diversity of bees and butterflies? Third, is community similarity correlated among butterflies, bees and forbs? That is, would two sites that are similar in composition relative to one taxonomic group (e.g., forbs) also harbor similar communities of the other taxa (e.g., bees and butterflies)?

\section{Methods}

Sampling sites

In 2003 and 2004, we sampled butterfly, bee and forb communities in 7 block habitats and 13 linear habitats in the northwest quarter of Iowa, USA (Fig. 1). All of the sample sites are tallgrass prairie remnants. The sample size of block sites was constrained by a priori qualifiers to include a site for sampling of a minimum size of 4 ha and a minimal cover $(<30 \%)$ of non-native plant species at the site. The specific block sites sampled represent a range of sizes (10-65 ha) and are all state prairie preserves. Criteria for linear sites included a minimal cover $(<30 \%)$ of non-native, aggressive plant species at the site, at least $300 \mathrm{~m}$ in length and a width no greater than $30 \mathrm{~m}$. These sites are owned and managed by privately owned railway lines or local governmental agencies.

At each of the seven block sites we established two $5 \mathrm{~m}$ by $100 \mathrm{~m}$ transects to survey bees, butterflies (Ries et al. 2001; Shepherd and Debinski 2005; Reeder et al. 2005) and forbs. Transects at block sites were at least $100 \mathrm{~m}$ from each other to minimize repeat sightings of the same individual pollinator. To minimize trampling effects at block sites, the transects used to survey bees and forbs associated with bees were parallel to and within $40 \mathrm{~m}$ of those transects used to survey butterflies and forbs associated with butterflies. At linear sites, two $5 \mathrm{~m}$ by $100 \mathrm{~m}$ transects were placed end-to-end approximately parallel to the habitat edge with at least $50 \mathrm{~m}$ separating them. Given the small size of linear remnants, we were unable to match the minimum distance between transects used at block sites, but trampling was minimized by limiting movement within the transect. All transects were placed in areas not dominated by wetland or non-native vegetation.

\section{Butterfly sampling}

In 2003 and 2004, we conducted three butterfly sampling surveys during the growing season (June, July, and August). During each of the three rounds, which lasted two to three weeks, we surveyed each site once for butterflies. Butterfly surveys were conducted between 09:30 and 18:30 h when temperatures were between $21^{\circ} \mathrm{C}$ and $35^{\circ} \mathrm{C}$, sustained winds were below $16 \mathrm{~km} / \mathrm{h}$, and the sun was shining. Butterfly surveys were conducted by walking each $100 \mathrm{~m}$ transect at a 
Fig. 1 Map of the prairie remnants in Northwest Iowa used to sample the bee, butterfly and forb communities shown by county in Iowa

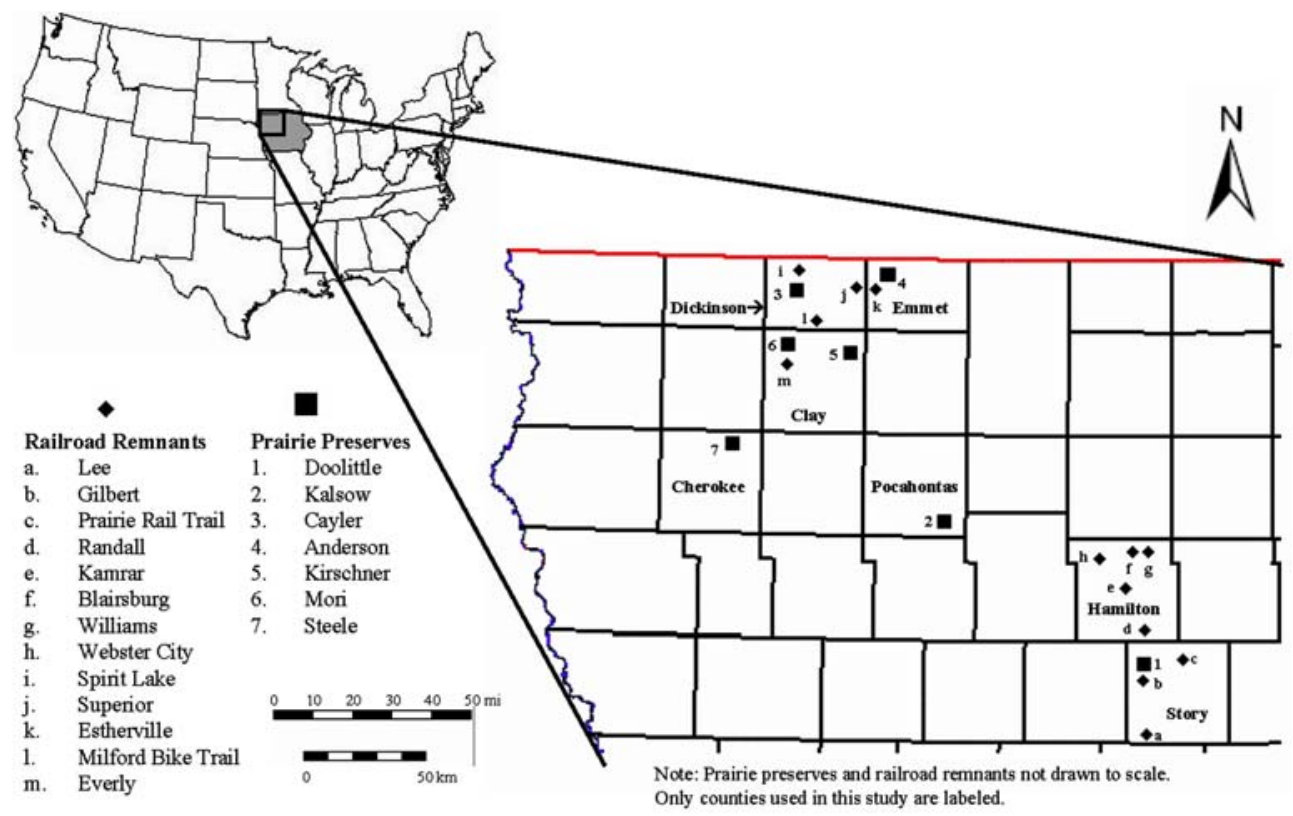

pace of $10 \mathrm{~m} / \mathrm{min}$ and observing butterflies within $2.5 \mathrm{~m}$ on either side and in front of the observer (Thomas 1983). The amount of time used to handle butterflies, record field notes, etc., was not counted towards sampling effort. During each visit, all butterflies (including skippers) were counted. Butterflies were identified on the wing if possible; otherwise they were netted. Vouchers were collected when necessary for identification and deposited in the laboratory of Dr. Diane Debinski.

\section{Bee sampling}

In 2003 and 2004, we collected bees at the study sites once per month in May, June, July and August. In 2003 and 2004 combined, a total of seven sites were not sampled in May because weather conditions prevented sampling all 20 sites within an eight-day period. We pan-trap sampled for bees along transects described above. Pan-trapping is a frequently used method to sample bees and other invertebrates (Evans and Bailey 1993; Aizen and Feinsinger 1994; Hodgson et al. 2005) at the community level, but has limitations for bee sampling if the study focus is a single plant species (Cane et al. 2000). Each transect consisted of 12 traps filled with soapy water. Pan traps were six oz. SOLO ${ }^{\circledR}$ bowls that were spray painted either fluorescent yellow, fluorescent blue, or left plain white because the different colors attract different bees (Leong and Thorp 1999; Toler et al. 2005). Within each transect, we placed the bowls on the ground at intervals of $10 \mathrm{~m}$ and pressed down the plants in an area of $0.25 \mathrm{~m}^{2}$ around the bowls to improve visibility to foraging bees. We used four bowls of each color in each transect arranged in a regular order; the order of colors was randomly chosen for each transect at the start of each sampling period.

We set out bowls between 08:00 and 12:00 $\mathrm{h}$ and collected the samples after six hours of "open trap time." Traps were considered open when the temperature was above $16^{\circ} \mathrm{C}$, the winds were less than $32 \mathrm{~km} / \mathrm{h}$, there was less than $60 \%$ cloud cover, and no precipitation had occurred. The insects in each trap were emptied into a small strainer and rinsed with water. Bees from a trap were separated from other insects at this stage and placed in a Whirl-Pak ${ }^{\circledR}$ bag with a $70 \%$ methanol/ethanol mixture. The bags were refrigerated until the samples were processed.

We identified bees to genus using Michener et al. (1994) and Michener (2000) and to species using monographic keys (Hemsley 2005) and Mitchell (1960 and 1962). To confirm identifications, some bees were compared to the collections at the University of Illinois's Museum of Natural History and the Snow Entomological Museum at the University of Kansas. Bees caught in 2003 of the genus Lasioglossum, subgenus Dialictus were identified in large part by $\mathrm{S}$. Droege (USGS, Patuxent Wildlife Center, MD), and bees of the subgenus Evylaeus were verified by R. McGinley (University of Illinois). Bee specimens were deposited in the laboratory of Dr. Stephen Hendrix.

Forb sampling

We sampled forbs available to pollinators during the same time periods that each pollinator guild was sampled. At all sites we quantified the forb diversity by 
directly counting the number of ramets for each forb species in flower in the $5 \mathrm{~m}$ by $100 \mathrm{~m}$ transect. Flowering forb species were identified using local and regional guides (McGregor et al. 1986; Christiansen and Müller 1999). Forbs were classified as either primarily visited by bees or by butterflies (Appendix). For butterflies, we used Opler and Krizek (1984), Panzer and Schwartz (1998), and Swengel and Swengel (1999) to classify forb species and for bees we used Robertson (1928) and unpublished lists of bee-visited species accumulated in associated studies (S.D. Hendrix et al., unpubl. data). Many forb species are visited by both guilds and appear in both categories.

\section{Data analysis}

\section{Species diversity}

We calculated species-accumulation curves using EstimateS (Colwell 2005) to assess the degree to which we have sufficiently sampled the bee and butterfly communities (Fig. 2). The curves for bees and butterflies are relatively similar to each other in that the majority of the species were accumulated given the degree of samples obtained. We used a non-parametric approach (Incidence-based Coverage Estimator, ICE) to estimate the predicted species richness with additional sampling. The ICE gives 36 species (of 31) for butterflies and 114 (of 86) for bees. We calculated a Shannon diversity index (base $\ln$ ) for each sampling site for butterflies, bees, and the forbs visited by both groups. Diversity indices were calculated on abundance data summed over transects and months for each year and then were averaged over the two years. Univariate regressions were conducted to analyze the correlation between taxa investigated. Simple linear regressions were performed using $\mathrm{JMP}^{\circledR} 5.1$ (JMP
2002). All variables were normally distributed (Kolmogrov-Smirnov test, $P>0.07$ ).

\section{Community composition}

Multivariate analyses were conducted to investigate the differences in community composition between linear and block sites. It is highly unlikely to have counted the same individual flowering ramet, bee, or butterfly in two consecutive months of sampling or in two transects within a site. Bee individuals are not captured repeatedly due to pan-trapping. Empirical estimates of daily butterfly movement rates are variable, but there are many species that travel a relatively small distance from the point at which they emerged (Peterson 1996; Auckland et al. 2004). Therefore, abundance data for multivariate analyses was summed over transects, months and years.

Correspondence analysis (CA) was used to identify differences in species assemblage between linear and block habitat sites (ter Braak 1995). The resulting plots display the relationship between the abundance of individual species (species scores) and sites (site scores). Locally non-abundant species (abundance $<10)$ were removed to avoid statistical biases in ordination analyses with such data (ter Braak and Šmilauer 2002). CAs were performed using abundance data from 31 bee species, 15 butterfly species, 98 bee-forb species and 60 butterfly-forb species. Ordinations were performed using function "cca" from the VEGAN library in R-Project (R Development Core Team 2004).

Discriminant analysis (DA) using $\mathrm{JMP}^{\circledR} 5.1$ (JMP 2002) was used to identify the predictability of classifying a site as linear or block based on the species composition. We eliminated species with low occurrences $(<15 \%$ frequency across all sites, i.e., $<3$ sites $)$ from this analysis because of statistical biases
Fig. 2 Species accumulation curves for bees and butterflies showing species accumulated with increasing samples

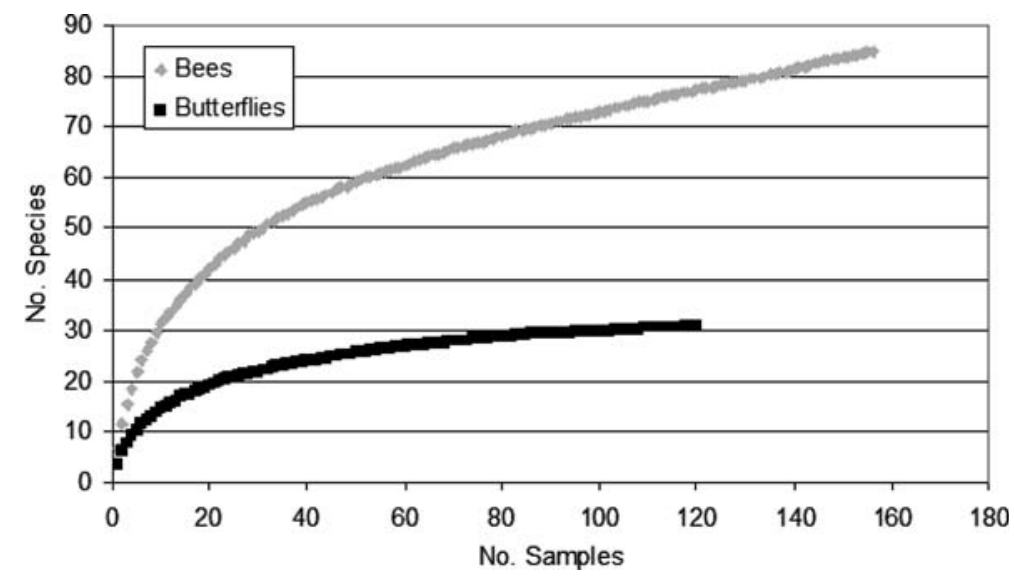


associated with such data. We chose step-wise selection of species and ran the analysis until $100 \%$ of the sites were correctly classified as their respective shape (block or linear). We ran ANOVA using $\mathrm{JMP}^{\circledR} 5.1$ (JMP 2002) to test for significant differences in abundance in the species that were used to separate block from linear habitats in each of the discriminate analyses. We only ran ANOVAs on species identified through DA and with total abundance $>50$ and a frequency of occurrence of $>40 \%$ (i.e., $>8$ sites) with significance set at the $P<0.05$ level.

We compared similarities among the community compositions at each site using Mantel tests to test for cross-taxon correlations between all pair-wise similarity matrices (Legendre and Legendre 1998). The null hypothesis of a Mantel test is of no relationship between the distances matrices in comparison. Mantel test significance was assessed using 999 Monte-Carlo permutations. We choose to use Bray-Curtis dissimilarity index for a measure of ecological distance between sites (Faith et al. 1987) and converted all values to represent similarity between sites. BrayCurtis distance matrices and Mantel tests were performed using R-project ( $\mathrm{R}$ Development Core Team 2004) and functions "vegdist" and "mantel" respectively from the VEGAN library.

\section{Results}

Species diversity patterns across taxa

Bees at a site were, on average, twice as high in richness, three times as high in abundance, and had greater diversity compared to butterflies (Table 1 ). The total number of bee species across all sites was more than twice that of butterflies. Rare species of bees represented by only one or two individuals in the sample accounted for $39.5 \%$ (34 species) of total richness. Average richness and diversity of bee-visited forbs at a site, but not their abundance, was greater than for butterfly-visited forbs. The total number of butterflyvisited forbs was $80 \%$ of the number of bee-visited forbs. Of all forb species, 59 were visited by both bees and butterflies.

Linear versus block community composition

Correspondence analysis of bee and butterfly communities and their associated forbs in block and linear sites gave mixed results (Fig. 3). The butterfly community and the forb communities associated with bees (Fig. 3a and d) separated into distinct linear and block sites, but the bee community and butterfly-visited forb community of block and linear sites did not separate well (Fig. 3b and c). Speyeria idalia was the only species correlated with block sites, while all other species were correlated with linear sites.

Discriminant analysis separated linear from block sites based on a relatively small group of species in bees and a similarly small group of species in the forbs associated with both bees and butterflies (Table 2). Linear and block sites can be distinguished based on abundance values of seven species of bees. Four of the seven species were cavity nesters, one of which was significantly greater in linear sites (Megachile). An additional, widely polylectic ground-nester (Melissodes) species was also more abundant in linear sites. Separation of forb species associated with pollinators required five species for bee-forbs and four species for butterfly-forbs, respectively (Table 2). Two of the total of nine key forb species (Apocynum and Dalea) occurred in both bee-visited and butterfly-visited discriminant analyses. Of the nine forb species in both analyses, five were in the Fabaceae family and two of these (Desmodium and Dalea) differed significantly in abundance in linear and block sites. Discriminant analysis required $63 \%$ of the total butterfly species (12 of 19 species) to separate linear from block sites and no individual species differed significantly in abundance between linear and block sites.

\section{Cross-taxon correlations}

Butterfly and bee species diversity were significantly negatively correlated across sites (Fig. 4), but neither

Table 1 Summary richness, abundance, and diversity statistics (ln Shannon-Wiener) per site totaled over the two years of the study for butterfly and bee taxa and the floral resources they use. $N=20$ sites for all variables

\begin{tabular}{|c|c|c|c|c|c|c|c|}
\hline \multirow[t]{2}{*}{ Taxon } & \multicolumn{2}{|c|}{ Richness } & \multicolumn{2}{|c|}{ Abundance } & \multicolumn{2}{|c|}{ Diversity } & \multirow[t]{2}{*}{ Total \# Species } \\
\hline & Mean & Std Dev & Mean & Std Dev & Mean & Std Dev & \\
\hline Butterfly & 10.9 & 2.61 & 56.75 & 19.11 & 1.56 & 0.20 & 31 \\
\hline Bee & 22.2 & 4.96 & 178.3 & 126.93 & 2.46 & 0.21 & 86 \\
\hline Bee-Forb & 37.4 & 7.10 & 3863.9 & 1633.6 & 2.39 & 0.41 & 100 \\
\hline Butterfly-Forb & 27.35 & 5.50 & 4404.2 & 2355.75 & 2.01 & 0.37 & 80 \\
\hline
\end{tabular}


Fig. 3 Correspondence analysis (CA) biplots for butterflies, bees, forbs associated with bees and forbs associated with butterflies. CA1 and CA2 indicate the first two dimensions in the correspondence analysis. Symbols indicate site shape $(\mathbf{O}=$ block sites; $\bigcirc=$ linear sites)
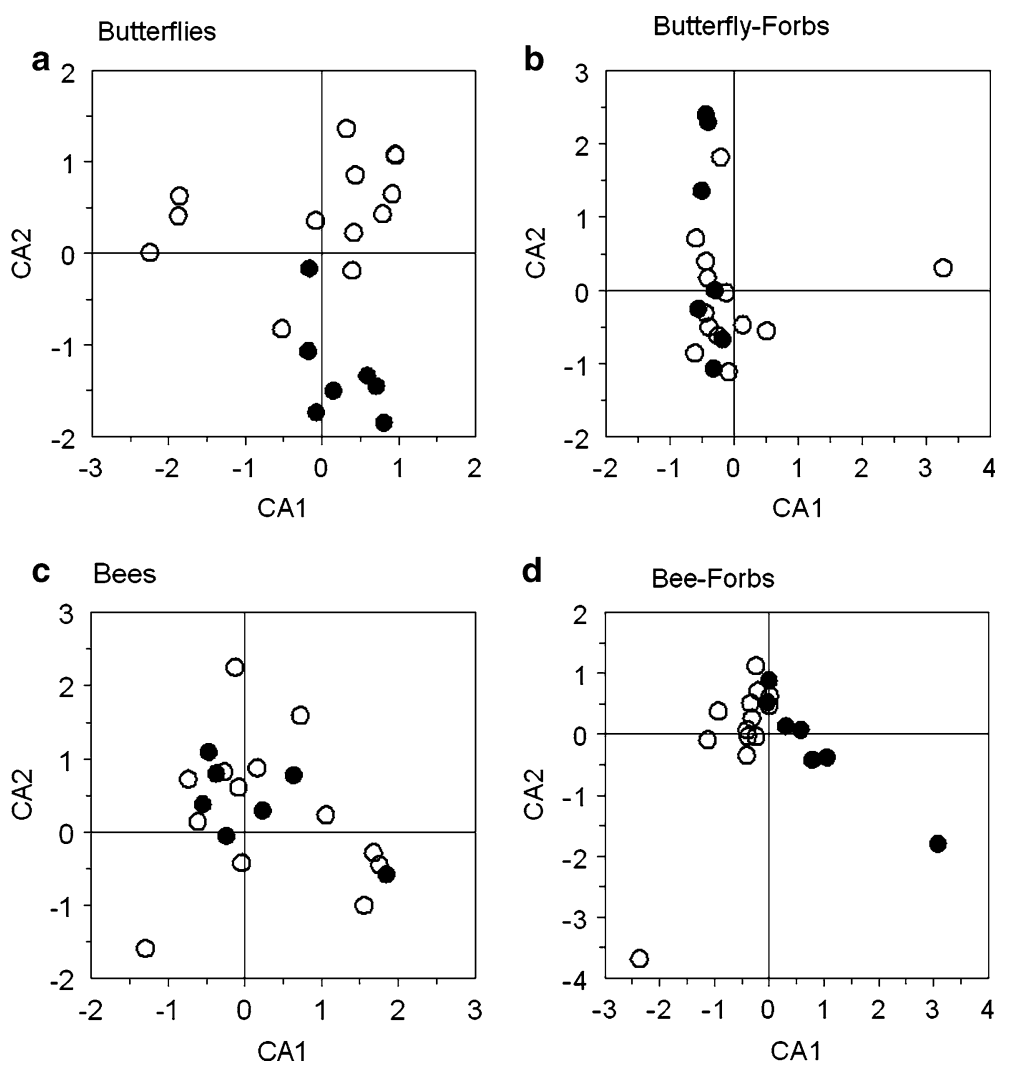

bee nor butterfly diversity was correlated with their respective forb species diversity across sites (both $\|\mathrm{r}\|$ values $<0.30$, both $P$ values $>0.211$ ). The bee community similarity matrix was positively correlated with the bee-forb similarity matrix $\left(R^{2}=0.1823, P=0.041\right)$. However, neither similarity matrices of butterflies versus their forbs nor butterfly versus bee were correlated (both $R^{2}$ values $<0.10$, both $P$ values $>0.15$ ). Given the differences in the butterfly community between linear and block habitats, we post hoc re-analyzed the cross-taxon correlations, this time comparing among block sites separately from linear sites. The results did not differ from those where all sites were included.

\section{Discussion}

In this study we examined differences in the butterfly, bee, and forb community composition in linear and block remnants, determined correlations between species diversity among butterflies, bees and forbs, and examined correlations of community similarity among butterflies, bees and forbs in prairie remnants. The results of this study show that the bee and butterfly community composition in linear and block tallgrass prairie remnants differ in subtle but important ways.
The butterfly communities have far fewer total species than bee communities (Table 1) and correspondence analysis shows a strong separation of species assemblages between linear and block habitats (Fig. 3a) because of consistent differences in abundance across a large number of species. Discriminant analysis reflects this pattern, using 12 of the 19 species (Table 2) to distinguish linear and block habitats. In contrast, discriminant analysis separates the bee communities based upon seven of 22 species per site (on average) (Table 2), but correspondence analysis does not separate the bee communities in linear and block habitats (Fig. 3c) because they share many relatively common bee species.

Differences in butterfly communities found in the correspondence analysis (Fig. 3a) may be related to the relative large edge to area ratio of linear sites affecting butterfly movement. For example, generalist butterflies like Danaus plexippus are not as affected by edges compared with specialists like Speyeria idalia (Ries and Debinski 2001). Additionally, butterfly specialists are disproportionately affected by fragmentation (Thomas et al. 1992; Summerville and Crist 2001; Warren et al. 2001). Differences in the bee communities between linear and block sites found through the discriminant analysis (Table 2), particularly the relative importance of cavity nesting bees in distinguishing linear sites, is 
Table 2 Discriminant analysis of bee, butterfly, bee-visited forbs and butterfly-visited forbs in block and linear sites

\begin{tabular}{|c|c|c|c|}
\hline \multirow[t]{2}{*}{ Taxon/Species } & \multicolumn{2}{|l|}{ Block } & \multirow{2}{*}{$\begin{array}{l}\text { Linear } \\
\text { Abundance } \\
\text { (\# sites) }\end{array}$} \\
\hline & Order & $\begin{array}{l}\text { Abundance } \\
\text { (\# sites) }\end{array}$ & \\
\hline \multicolumn{4}{|l|}{ Bees $(\#$ spp. $=34)$} \\
\hline Megachile brevis & 1 & $4(3)$ & $64(13)^{* *}$ \\
\hline Melissodes bimaculata & 2 & $1(1)$ & $27(9)$ \\
\hline Hylaeus affinis & 3 & $49(7)$ & $115(9)$ \\
\hline Andrena wilkella & 4 & $8(4)$ & $2(2)$ \\
\hline Andrena ziziae & 5 & $10(3)$ & $9(5)$ \\
\hline Hoplitis producta & 6 & $3(2)$ & $6(3)$ \\
\hline Osmia simillina & 7 & $3(2)$ & $18(5)$ \\
\hline \multicolumn{4}{|l|}{ Butterflies (\# spp. = 19) } \\
\hline Colias philodice & 1 & $12(5)$ & $4(4)$ \\
\hline Danaus plexippus & 2 & $49(6)$ & $63(12)$ \\
\hline Phyciodes tharos & 3 & $26(6)$ & $43(11)$ \\
\hline Polites peckius & 4 & $1(1)$ & $12(6)$ \\
\hline Cercyonis pegala & 5 & $19(4)$ & $111(10)$ \\
\hline Polites mystic & 6 & $12(3)$ & $26(5)$ \\
\hline Vanessa cardui & 7 & $25(5)$ & $38(10)$ \\
\hline Speyeria idalia & 8 & $28(6)$ & $50(7)$ \\
\hline Lycaena dion & 9 & $1(1)$ & $7(2)$ \\
\hline Atrytone logan & 10 & $4(3)$ & $20(5)$ \\
\hline Vanessa atalanta & 11 & $5(2)$ & $15(7)$ \\
\hline Speyeria cybele & 12 & $3(2)$ & $7(5)$ \\
\hline \multicolumn{4}{|l|}{ Bee-Forbs (\# spp. = 73) } \\
\hline Desmodium canadensis & 1 & $113(3)^{*}$ & $16(2)$ \\
\hline Apocynum cannabinum & 2 & $13(3)$ & $5(3)$ \\
\hline Dalea candida & 3 & $209(6)^{*}$ & $15(2)$ \\
\hline Lespedeza capitata & 4 & $8(3)$ & $0(0)$ \\
\hline Psoralea argophylla & 5 & $282(5)$ & $100(5)$ \\
\hline \multicolumn{4}{|c|}{ Butterfly-Forbs (\# spp. = 51) } \\
\hline Dalea candida & 1 & $339(6)^{*}$ & $5(1)$ \\
\hline Apocynum cannabinum & 2 & $90(3)$ & $8(3)$ \\
\hline Lathyrus sp. & 3 & $898(6)$ & $663(6)$ \\
\hline Asclepias sullivantii & 4 & $66(3)$ & $4(2)$ \\
\hline
\end{tabular}

Species are listed in the order in which they were entered into the model in a step-wise fashion. Blocks separate from linear sites with $100 \%$ accuracy using the species abundance. Significant differences in abundance between linear and block sites based on ANOVAs are indicated as follows:

$* P<0.05, * * P<0.001$

likely due to management practices (or lack of) allowing accumulation of stems at linear sites because of infrequent fires. Block sites are routinely burned as part of their management programs. Although 10 of the 13 sites are active railways with railroad ties, cavity nesting bees do not bore into railway ties to nest unless they are decaying and cracking (J. Cane, pers. comm.). Our sample size for burned versus unburned sites did not allow us to test this hypothesis of management effects on bees and butterflies, although responses to fire are not consistent even across prairie-dependent butterflies (Vogel 2006). In general, restraint in

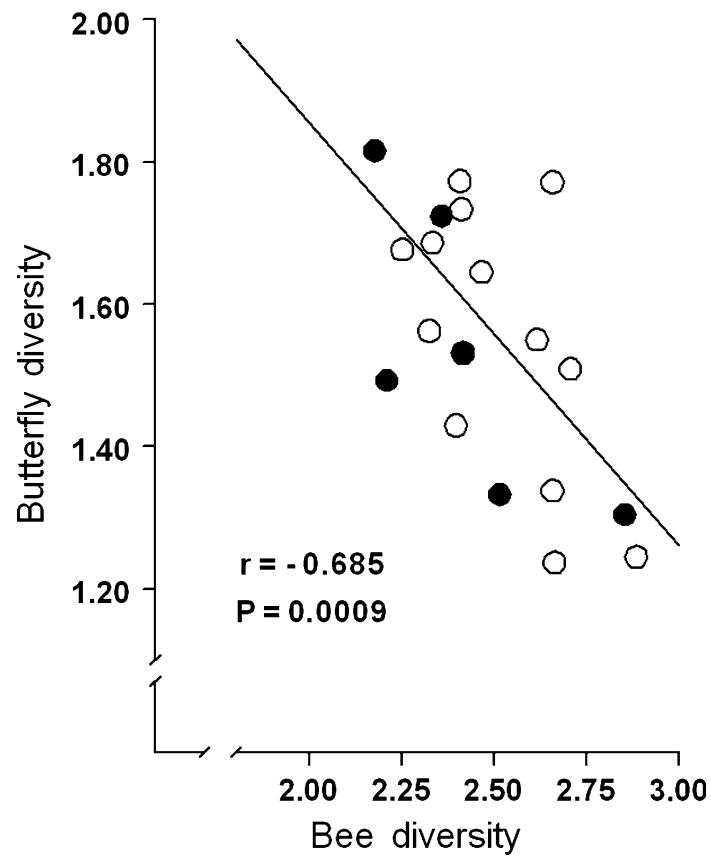

Fig. 4 Cross-taxon correlation between butterfly diversity and bee diversity at study sites $(\bullet=$ block sites; $\bigcirc=$ linear sites $)$

burning is recommended to protect many prairie invertebrates (Panzer 2002). The number of rare species of bees in our samples is not unusual; many bee communities have large numbers of rare species (Williams et al. 2001; Potts et al. 2003).

The forb communities associated with both the butterflies and bees in linear and block prairie habitats are distinguished by seven different species using discriminant analysis (Table 2). Five of these species (Asclepias, Dalea, Desmodium, Lathyrus, and Psoralea) have coefficients of conservation greater than 5 (maximum 10; Swink and Wilhelm 1994) indicating that they are relatively habitat sensitive. In every case, the abundance of these forbs is higher in block relative to linear habitats, and in most cases the frequency of occurrence is higher on block relative to linear habitats. Thus, many of the small prairie remnants examined, are degraded to some degree. In particular, the legumes with their $\mathrm{N}$-fixing symbionts have an advantage in open, sunny nitrogen poor sites subject to fires which volatilize $\mathrm{N}$ stocks, but lose their advantage when fires are eliminated and $\mathrm{N}$ stocks build up (Leach and Givnish 1996).

In terms of cross-taxon correlations in species diversity, we found little evidence of congruence between pollinator communities except for a negative correlation between bee and butterfly diversity (Fig. 4). This inverse relationship indicates either that bees and butterflies are searching for very different 
microhabitat conditions or potential competitive exclusion for nectar resources may exist between the two pollinator taxa studied. Because many species of bees are ground nesters, the type of soil, topography, and moisture levels at a local site may have important implications for bees that may not be quite as important to butterflies. Similarly, larval host plant preference, which is very important for many butterfly species, has no corollary in the life history of bees. Although little research has been conducted on competition between bees and butterflies, Douglas (1986) notes that when nectar-bearing flowers are scarce, or when competition for nectar with other pollinators such as bees is high, butterflies may use rather unorthodox sources for food such as grass influorescences (Neck 1980). Thus, there is some documentation of bee-butterfly competition for nectar.

The lack of congruence in similarity between butterflies, bees, and their respective forbs in this study is similar to numerous other studies that find little if any congruence in species richness (Oliver and Beattie 1996; Howard et al. 1998; Oliver et al. 1998; Negi and Gadgil 2002; Su et al. 2004) or community complementarity (Negi and Gadgil 2002; Danielson and Treadaway 2004) at many different spatial scales of investigation (e.g., habitat patch, regional). More specifically, other studies in the Midwest prairie ecosystem show similar results with respect to uncorrelated butterfly and forb diversity values (Reeder et al. 2005; Shepherd and Debinski 2005). In contrast, examples of congruence have been found where multiple taxa respond to a common gradient (Su et al. 2004) or have similar patterns of biogeography (Howard et al. 1998).

Our study does not address the question of whether or not the bee and butterfly species we find at the highquality block and linear prairie sites are remnant dependent. To make such a determination will require detailed studies of the location of nests of bees and host plant use of immature stages of butterflies. Such studies, however, will be necessary to estimate longlong viability of these populations.

In conclusion, our study shows that the conservation of bee and butterfly pollinators in prairie remnants will not benefit from targeting one pollinator taxon as an indicator of the other. In fact, quite different sites may be necessary to preserve both pollinator taxa. The lack of influence of local floral characteristics on pollinator communities indicates that landscape components may be critical to diversity of pollinators in prairie remnants (Hines and Hendrix 2005; Davis 2005), making their conservation difficult because remnants are small and surrounding habitat is managed for human purposes. Lastly, it is important to remember that potentially many of the prairie dependent species no longer exist in these areas (Schlicht and Orwig 1998). Thus, we are dealing with a truncated species assemblage and the goal of conservation is prevent further erosion of pollinator biodiversity which can lead to reduced plant reproduction and possible loss of species.

Acknowledgements We thank the Iowa Department of Transportation-Living Roadway Trust, Iowa State University_Office of the Vice Provost for Research, and the University of Iowa-Center for Global and Regional Environmental Research for financial support of this project. This research would not have been possible without permission to survey from private and public land owners. Thanks to research technicians $\mathrm{K}$. Gaddis, C. Hemsley, A. Hill, K. Kwaiser, M. Oppold, A. Skibbe, C. Swanson, J. Vogel, and M. Wendel for field and laboratory assistance.

\section{Appendix}

List of butterfly and bee visited forbs used in our analyses

\begin{tabular}{|c|c|c|}
\hline Forb Species & Bee-Forbs & Butterfly-Forbs \\
\hline Achillea millefolium & $\mathrm{x}$ & $\mathrm{x}$ \\
\hline Allium canadense & & $\mathrm{x}$ \\
\hline Allium stellatum & $\mathrm{x}$ & \\
\hline Amorpha canescens & $\mathrm{x}$ & $\mathrm{x}$ \\
\hline Amorpha nana & $\mathrm{x}$ & \\
\hline Anemone canadensis & $\mathrm{x}$ & \\
\hline Anemone cylindrica & $\mathrm{x}$ & \\
\hline Apocynum cannabinum & $\mathrm{x}$ & $\mathrm{x}$ \\
\hline Asclepias incarnata & $\mathrm{x}$ & $\mathrm{x}$ \\
\hline Asclepias sullivantii & & $\mathrm{x}$ \\
\hline Asclepias syriaca & $\mathrm{x}$ & $\mathrm{x}$ \\
\hline Asclepias tuberosa & $\mathrm{x}$ & $\mathrm{x}$ \\
\hline Asclepias verticillata & $\mathrm{x}$ & \\
\hline Asclepias viridiflora & & $\mathrm{x}$ \\
\hline Astragalus canadensis & $\mathrm{x}$ & \\
\hline Astragalus crassicarpus & $\mathrm{x}$ & \\
\hline Baptisia alba & $\mathrm{x}$ & \\
\hline Baptisia bracteata & $\mathrm{x}$ & \\
\hline Barbarea vulgaris & $\mathrm{x}$ & \\
\hline Brickellia eupatorioides & & $\mathrm{x}$ \\
\hline Calylophus serrulatus & $\mathrm{x}$ & \\
\hline Ceanothus americanus & $\mathrm{x}$ & $\mathrm{x}$ \\
\hline Chamaecrista fasciculata & & $\mathrm{x}$ \\
\hline Chrysanthemum leucanthemum & & $\mathrm{x}$ \\
\hline Cicuta maculata & $\mathrm{x}$ & $\mathrm{x}$ \\
\hline Cirsium altissimum & $\mathrm{x}$ & $\mathrm{x}$ \\
\hline Cirsium arvense & $\mathrm{x}$ & $\mathrm{x}$ \\
\hline Cirsium discolor & $\mathrm{x}$ & \\
\hline Cirsium undulatum & & $\mathrm{x}$ \\
\hline Comandra umbellata & & $\mathrm{x}$ \\
\hline Convolvulus arvensis & $\mathrm{x}$ & $\mathrm{x}$ \\
\hline Coreopsis palmata & $\mathrm{x}$ & $\mathrm{x}$ \\
\hline Dalea candida & $\mathrm{x}$ & $\mathrm{x}$ \\
\hline Dalea purpurea & $\mathrm{x}$ & $\mathrm{x}$ \\
\hline Daucus carota & $\mathrm{x}$ & $\mathrm{x}$ \\
\hline
\end{tabular}


Appendix continued

\begin{tabular}{|c|c|c|}
\hline Forb Species & Bee-Forbs & Butterfly-Forbs \\
\hline Desmodium canadense & $\mathrm{x}$ & $\mathrm{x}$ \\
\hline Dodecatheon meadia & $\mathrm{x}$ & \\
\hline Echinacea pallida & $\mathrm{x}$ & $\mathrm{x}$ \\
\hline Erigeron strigosus & $\mathrm{x}$ & $\mathrm{x}$ \\
\hline Eryngium yuccifolium & $\mathrm{x}$ & $\mathrm{x}$ \\
\hline Euphorbia corollata & $\mathrm{x}$ & $\mathrm{x}$ \\
\hline Euphorbia esula & & $\mathrm{x}$ \\
\hline Fragaria virginiana & $\mathrm{x}$ & $\mathrm{x}$ \\
\hline Helenium autumnale & $\mathrm{x}$ & $\mathrm{x}$ \\
\hline Helianthus grosseratus & $\mathrm{x}$ & $\mathrm{x}$ \\
\hline Helianthus maxmiliani & $\mathrm{x}$ & \\
\hline Helianthus rigidus & $\mathrm{x}$ & \\
\hline Heliopsis helianthoides & $\mathrm{x}$ & $\mathrm{x}$ \\
\hline Heuchera richardsonii & $\mathrm{x}$ & \\
\hline Hypericum perforatum & $\mathrm{x}$ & \\
\hline Hypoxis hirsuta & $\mathrm{x}$ & \\
\hline Ipomoea pandurata & & $\mathrm{x}$ \\
\hline Ipomoea purpurea & & $\mathrm{x}$ \\
\hline Lathyrus sp. & & $\mathrm{x}$ \\
\hline Lespedeza capitata & $\mathrm{x}$ & $\mathrm{x}$ \\
\hline Liatris aspera & $\mathrm{x}$ & $\mathrm{x}$ \\
\hline Liatris pycnostachya & $\mathrm{x}$ & $\mathrm{x}$ \\
\hline Lilium philadelphicum & $\mathrm{x}$ & $\mathrm{x}$ \\
\hline Lithospermum canescens & $\mathrm{x}$ & $\mathrm{x}$ \\
\hline Lobelia spicata & $\mathrm{x}$ & $\mathrm{x}$ \\
\hline Lotus corniculatus & $\mathrm{x}$ & $\mathrm{x}$ \\
\hline Lysimachia ciliate & $\mathrm{x}$ & \\
\hline Lythrum alatum & $\mathrm{x}$ & $\mathrm{x}$ \\
\hline Medicago lupulina & & $\mathrm{x}$ \\
\hline Medicago sativa & & $\mathrm{x}$ \\
\hline Melilotus alba & $\mathrm{x}$ & $\mathrm{x}$ \\
\hline Melilotus officinalis & $\mathrm{x}$ & $\mathrm{x}$ \\
\hline Monarda fistulosa & $\mathrm{x}$ & $\mathrm{x}$ \\
\hline Nepeta cataria & $\mathrm{x}$ & \\
\hline Oenothera villosa & $\mathrm{x}$ & \\
\hline Onosmodium molle & & $\mathrm{x}$ \\
\hline Oxalis dillenii & $\mathrm{x}$ & \\
\hline Oxalis stricta & & $\mathrm{x}$ \\
\hline Oxalis violacea & $\mathrm{x}$ & \\
\hline Oxypolis rigidior & $\mathrm{x}$ & \\
\hline Pastinaca sativa & $\mathrm{x}$ & $\mathrm{x}$ \\
\hline Pedicularis canadensis & $\mathrm{x}$ & \\
\hline Pediomelum argophyllum & $\mathrm{x}$ & $\mathrm{x}$ \\
\hline Penstemon digitalis & $\mathrm{x}$ & \\
\hline Phlox pilosa & & $\mathrm{x}$ \\
\hline Plantago patagonica & $\mathrm{x}$ & \\
\hline Polygonum amphibium & & $\mathrm{x}$ \\
\hline Polygonum pensylvanicum & $\mathrm{x}$ & $\mathrm{x}$ \\
\hline Potentilla arguta & $\mathrm{x}$ & \\
\hline Potentilla recta & $\mathrm{x}$ & $\mathrm{x}$ \\
\hline Potentilla simplex & $\mathrm{x}$ & $\mathrm{x}$ \\
\hline Prunella vulgaris & $\mathrm{x}$ & $\mathrm{x}$ \\
\hline Pycnanthemum virginianum & $\mathrm{x}$ & $\mathrm{x}$ \\
\hline Ranunculus fascicularis & $\mathrm{x}$ & \\
\hline Ratibida pinnata & $\mathrm{x}$ & $\mathrm{x}$ \\
\hline Rosa arkansana & $\mathrm{x}$ & $\mathrm{x}$ \\
\hline Rudbeckia hirta & $\mathrm{x}$ & $\mathrm{x}$ \\
\hline Rudbeckia subtomentosa & $\mathrm{x}$ & $\mathrm{x}$ \\
\hline Rumex altissimus & & $\mathrm{x}$ \\
\hline Scutellaria parvula & & $\mathrm{x}$ \\
\hline Senecio plattensis & $\mathrm{x}$ & \\
\hline Silphium integrifolium & $\mathrm{x}$ & $\mathrm{x}$ \\
\hline
\end{tabular}

Appendix continued

\begin{tabular}{lll}
\hline Forb Species & Bee-Forbs & Butterfly-Forbs \\
\hline Silphium laciniatum & $\mathrm{x}$ & $\mathrm{x}$ \\
Silphium perfoliatum & $\mathrm{x}$ & $\mathrm{x}$ \\
Sisymbrium loeselii & & $\mathrm{x}$ \\
Sisyrinchium campestre & $\mathrm{x}$ & \\
Sium suave & $\mathrm{x}$ & $\mathrm{x}$ \\
Solidago canadensis & $\mathrm{x}$ & \\
Solidago gigantea & $\mathrm{x}$ & $\mathrm{x}$ \\
Solidago missouriensis & $\mathrm{x}$ & \\
Solidago rigida & $\mathrm{x}$ & \\
Sonchus arvensis & $\mathrm{x}$ & \\
Stachys palustris & $\mathrm{x}$ & $\mathrm{x}$ \\
Taraxacum officinale & $\mathrm{x}$ & \\
Teucrium canadensis & $\mathrm{x}$ & \\
Tradescantia bracteata & $\mathrm{x}$ & $\mathrm{x}$ \\
Trifolium pretense & $\mathrm{x}$ & $\mathrm{x}$ \\
Trifolium repens & & \\
Verbena hastate & $\mathrm{x}$ & $\mathrm{x}$ \\
Verbena stricta & $\mathrm{x}$ & $\mathrm{x}$ \\
Vernonia fasiculata & $\mathrm{x}$ & $\mathrm{x}$ \\
Veronicastrum virginicum & $\mathrm{x}$ & $\mathrm{x}$ \\
Vicia americana & $\mathrm{x}$ & $\mathrm{x}$ \\
Viola pedatifida & $\mathrm{x}$ & $\mathrm{x}$ \\
Viola pratincola & $\mathrm{x}$ & \\
Zigadenus elegans & & \\
Zizia aurea & & \\
\hline
\end{tabular}

\section{References}

Allen-Wardell G, Bernhardt P, Bitner R et al (1998) The potential consequences of pollinator declines on the conservation of biodiversity and stability of food crop yields. Conserv Biol 12:8-17

Aizen MA, Feinsinger P (1994) Habitat fragmentation, native insect pollinators, and feral honey bees in Argentine 'Chaco Serrano'. Ecol Applications 4:378-392

Auckland J, Debinski DM, Clark WR (2004) Survival, movement, and resource use of the butterfly Parnassius clodius. Ecol Entomol 29:139-149

Biesmeijer JC, Roberts SPM, Reemer M et al (2006) Parallel declines in pollinators and insect-pollinated plants in Britain and the Netherlands. Science 313:351-354

Buchmann SL, Nabhan GP (1996) The forgotten pollinators. Shearwater Books, Washington D.C., USA

Cane JH, Minckley RL, Kervin LJ (2000) Sampling bees (Hymenoptera: Apiformes) for pollinator community studies: Pitfalls of pan-trapping. J Kansas Entomol Soc 73: 225231

Cane JH, Minckley RL, Kervin LJ et al (2006) Complex responses within a desert bee guild (Hymenoptera: Apiformes) to urban habitat fragmentation. Ecol Appl 16:632-644

Cane JH, Tepedino VJ (2001) Causes and extent of declines among native North American invertebrate pollinators: detection, evidence, and consequences. Conserv Ecol 5:U17-U26

Christiansen J, Müller M (1999). An illustrated guide to Iowa prairie plants. University of Iowa Press, Iowa City, Iowa

Colwell RK (2005) EstimateS: Statistical estimation of species richness and shared species from samples. Version 7.5. 
User's Guide and application published at: http://purl.oclc.org/estimates

Constanza R, d'Arge R, de Groot R et al (1997) The value of the world's ecosystem services and natural capital. Nature 387 : 253-260

Croxton PJ, Hann JP, Greatorex-Davies JN et al (2005) Linear hotspots? The floral and butterfly diversity of green lanes. Biol Conserv 121: 579-584

Danielson J, Treadaway CG (2004) Priority conservation areas for butterflies (Lepidoptera: Rhopalocera) in the Philippine islands. Anim Conserv 7: 79-92

Davis, JD (2005) Butterfly community composition in fragmented habitats: Effects of patch shape and spatial scale. MS Thesis, Iowa State University

Douglas MM (1986) The lives of butterflies. The University of Michigan Press, Ann Arbor, MI

Evans EW, Bailey KW (1993) Sampling grasshoppers (Orthoptera: Acrididae) in Utah grasslands: pan traps versus sweep sampling. J Kansas Entomol Soc 66: 214-222

Faith DP, Minchin PR, Belbin L (1987) Compositional dissimilarity as a robust measure of ecological distance. Vegetatio 69:57-68

Hemsley C (2005) Diversity, abundance, and similarity of solitary bee communities in tallgrass prairie fragments. MS Thesis, University of Iowa

Herzberg R, Pearson J (2001) The guide to Iowa's state preserves. University of Iowa Press, Iowa City

Hines H, Hendrix SD (2005) Bumble bee (Hymenoptera: Apidae) diversity and abundance in tallgrass prairie patches: effects of local and landscape floral resources. Environ Entomol 34:1477-1484

Hodgson EW, Koch RL, Ragsdale DW (2005) Pan trapping for soybean aphid (Homoptera: Apididae) in Minnesota soybean fields. J Entomol Sci 40:409-419

Howard PC, Viskanic P, Davenport TRB, et al (1998) Complementarity and the use of indicator groups for reserve selection in Uganda. Nature 394:472-475

JMP, Version 5 (2002) SAS Institute Inc. Cary, North Carolina, USA

Legendre P, Legendre L (1998) Numerical ecology. Elsevier Science BV, Amsterdam

Leach MK, Givnish TJ (1996) Ecological determinants of species loss in remnant prairies. Science 173:1555-1558

Leong JM, Thorp RW (1999) Colour-coded sampling: the pan trap colour preferences of oligolectic and nonoligolectic bees associated with a vernal pool plant. Ecol Entomol 24:329-335

McGregor RL, Barkley TM, Brooks RE, Schofield EK (eds) (1986) Flora of the Great Plains. University Press of Kansas, Lawrence

Michener CD (2000) The bees of the world. Johns Hopkins University Press, Baltimore

Michener CD, McGinley RJ, Danforth BN (1994) The bee genera of North and Central America (Hymenoptera: Apoidea). Smithsonian Institution Press, Washington, D.C

Mitchell TB (1960) Bees of the eastern United States, Vol 1. Raleigh, North Carolina Agricultural Experiment Station, $538 \mathrm{p}$

Mitchell TB (1962) Bees of the eastern United States, Vol 2. Raleigh, North Carolina Agricultural Experiment Station, $557 \mathrm{p}$

Neck R (1980) Utilization of grass influorescences as adult resources by Rhopalocera. J Lep Soc 34:261-62

Negi HR, Gadgil M (2002) Cross-taxon surrogacy of biodiversity in the Indian Garhwal Himalaya. Biol Conserv 105:143-155
Oliver I, Beattie AJ (1996) Designing a cost-effective invertebrate survey: a test of methods for rapid assessment of biodiversity. Ecol Applications 6:594-607

Oliver I, Beattie AJ, York A (1998) Spatial fidelity of plant, vertebrate, and invertebrate assemblages in multiple-use forest in eastern Australia. Conserv Biol 12:822-835

Opler PA, Krizek GO (1984) Butterflies east of the Great Plains: an illustrated natural history. The John Hopkins University Press, Baltimore, Maryland, USA

Panzer R (2002) Compatibility of prescribed burning with the conservation of insects in small, isolated prairie preserves. Conserv Biol 16:1296-1307

Panzer R, Schwartz MW (1998) Effectiveness of a vegetationbased approach to insect conservation. Conserv Biol 12:693702

Peterson MA (1996) Long-distance gene flow in the sedentary butterfly, Euphilotes enoptes (Lepidoptera: Lycaenidae). Evolution 50:1990-1999

Potts SG, Vulliamy B, Dafni A, et al (2003) Linking bees and flower: how do floral communities structure pollinator communities? Ecology 84:2628-2642

R Development Core Team. (2004) R: A language and environment for statistical computing. R Foundation for Statistical Computing, Vienna, Austria

Rathcke BJ, Jules ES (1993) Habitat fragmentation and plantpollinator interactions. Curr Sci 65:273-277

Reeder KF, Debinski DM, Danielson BJ (2005) Factors affecting butterfly use of filter strips in Midwestern USA. Agr Ecosyst Environ 109:40-47

Ries L, Debinski DM (2001) Butterfly responses to habitat edges in the highly fragmented prairies of Central Iowa. J Anim Ecol 70:840-852

Ries L, Debinski DM, Wieland ML (2001) Conservation value of roadside prairie restoration to butterfly communities. Conserv Biol 15:401-411

Robertson C (1928) Flowers and insects. Lists of visitors to four hundred and fifty-three flowers. Science Press Printing, Lancaster

Samson F, Knopf F (1994) Prairie conservation in North America. BioScience 44:418-421

Schlicht DW, Orwig TT (1998) The status of Iowa's Lepidoptera. J Iowa Acad Sci 105:82-88

Shepherd S, Debinski DM (2005) Evaluation of isolated and integrated prairie reconstructions as habitat for prairie butterflies. Biol Conserv 126:51-61

Steffan-Dewenter I, Munzenberg U, Burger C, et al (2002) Scaledependent effects of landscape context on three pollinator guilds. Ecology 83:1421-1432

Steffan-Dewenter I, Potts SG, Packer L (2005) Pollinator diversity and crop pollination services are at risk. Trends Ecol Evol 20:651-652

Steffan-Dewenter I, Tscharntke T (1999) Effects of habitat isolation on pollinator communities and seed set. Oecologia 121:432-440

Su JC, Debinski DM, Jakubauskas ME, Kindscher K (2004) Beyond species richness: community similarity as a measure of cross-taxon congruence for coarse-filter conservation. Conserv Biol 18:167-173

Summerville K, Crist T (2001) Effects of experimental habitat fragmentation on patch use by butterflies and skippers (Lepidoptera). Ecology 82:1360-1370

Swengel AB, Swengel SR (1999) Observations of prairie skippers (Oarisma poweshiek, Hesperia dacotae, H. ottoe, H. leonardus pawnee, and Atrytone arogos iowa) (Lepidoptera : Hesperiidae) in Iowa, Minnesota, and North Dakota during 1988-1997. Great Lakes Entomol 32:267-292 
Swink F, Wilhelm G (1994) Plants of the Chicago region, 4th edn. Indiana Academy of Science, Indianapolis, Indiana, USA

ter Braak CJF (1995) Ordination. In: Jongman RHG, ter Braak CJF, van Tongeren PFR (eds.) Data analysis in community and landscape ecology, 2nd edn. Cambridge University Press, Cambridge, UK

ter Braak CJF, Šmilauer P (2002) CANOCO reference manual and user's guide to CANOCO: software for canonical community ordination (ver. 4.5). Microcomputer Power, Ithaca, New York, USA

Thomas CD, Thomas JA, Warren MS (1992) Distribution of occupied and vacant butterfly habitats in fragmented landscapes. Oecologia 92:563-567

Thomas JA (1983) A quick method for estimating butterfly numbers during surveys. Biol Conserv 27:195-211
Thomas JA (2005) Monitoring change in the abundance and distribution of insects using butterflies and other indicator groups. Phil Trans R Soc B 360:339-357

Toler TR, Evans EW, Tepedino VJ (2005) Pan-trapping for bees (Hymenoptera: Apiformes) in Utah's Desert: the importance of color diversity. Pan-Pacific Entomologist 81:103113

Vogel JA (2006) Grassland butterfly responses to prairie restoration: Effects of prescribed fire and grazing. M.S. Thesis, Iowa State University

Warren MS, Hill JK, Thomas JA, et al (2001) Rapid responses of British butterflies to opposing forces of climate and habitat change. Nature 414:65-69

Williams NM, Minckley RL, Silveira FA (2001) Variation in native bee faunas and its implications for detecting community changes. Conserv Biol 5:U57-U86 